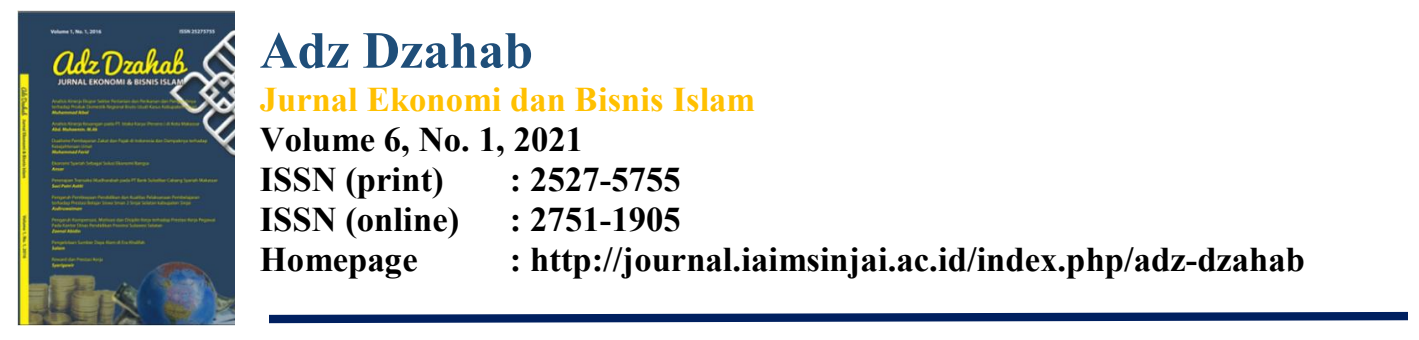

\title{
ANALISIS DETERMINAN MINAT MAHASISWA DALAM BERINVESTASI DI PASAR MODAL SYARIAH
}

\author{
Yuni Inawati', Muhammad Syariful Anam², Pandu Nur Wicaksono ${ }^{3}$, Nailis \\ Safaah $^{4}$, Yusvita Nena Arinta ${ }^{5}$ \\ 1,2,3,4,5Institut Agama Islam Negeri (IAIN) Salatiga, Jl. Tentara Pelajar No. 2, Kota Salatiga \\ Korespondesi Penulis.E-mail: yuniinawati88@gmail.com, Tlp:085828320901
}

\begin{abstract}
Abstrak
Penelitian analisis determinan minat mahasiswa dalam berinvestasi di pasar modal syariah ini bertujuan untuk menganalisis pengaruh religiusitas, pengetahuan, manfaat dan modal minimum investasi terhadap minat mahasiswa dalam berinvestasi di pasar modal syariah. Jenis penelitian ini jenis penelitian kuantitatif yang bertujuan untuk melakukan analisis terhadap determinan minat mahasiswa untuk menginvestasikan uangnya di pasar modal syariah. Mengenai variabel independen yang digunakan yaitu religiusitas, pengetahuan, manfaat dan modal minimum investasi, adapun variabel dependen yang dipakai adalah minat berinvestasi di pasar modal syariah. Populasi dari penelitian ini yaitu mahasiswa Institut Agama Islam Negeri (IAIN) Salatiga. Sedangkan untuk penentuan jumlah sampel dilakukan dengan menggunakan rumus slovin dan kemudian diperoleh sampel sabanyak 100 mahasiswa. Teknik analisis data yang digunakan yaitu dengan analisis regresi linier berganda. Berdasarkan hasil analisis yang telah dilakukan, dapat disimpulkan bahwa secara parsial religiusitas dan manfaat berpengaruh tidak signifikan terhadap minat berinvestasi di pasar modal syariah. Sedangkan pengetahuan dan modal minimum investasi secara parsial berpengaruh positif dan signifikan terhadap minat berinvestasi di pasar modal syariah. Kemudian secara simultan religiusitas, pengetahuan, manfaat dan modal minimum investasi berpengaruh secara signifikan terhadap minat berinvestasi di pasar modal syariah.
\end{abstract}

Kata Kunci: Religiusitas, Pengetahuan, Manfaat, Modal Minimum Investasi, Minat Berinvestasi 


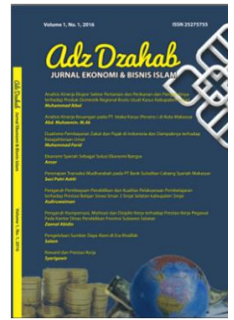

Adz Dzahab

Jurnal Ekonomi dan Bisnis Islam

Volume 6, No. 1, 2021

ISSN (print) : 2527-5755

ISSN (online) : 2751-1905

Homepage : http://journal.iaimsinjai.ac.id/index.php/adz-dzahab

\section{Pendahuluan}

Perkembangan investasi di Indonesia dewasa ini patut untuk mendapatkan apresiasi. Dapat dilihat dari data Badan Koordinasi Penanaman Modal (BKPM) bahwa realisasi investasi pada tahun 2020 tepatnya triwulan III mencapai angka Rp. 209,0 triliun atau mengalami peningkatan sebesar 8,9 persen dari Triwulan sebelumnya yang mencapai Rp. 191,9 triliun. Tingkat investasi Penanaman Modal dalam Negeri (PMDN) turut mengalami peningkatan sebesar 49,2 persen atau Rp. 102,9 triliun (BKPM, 2020). Data tersebut menunjukkan bahwa masyarakat Indonesia memiliki minat berinvestasi yang tinggi. Pasar modal merupakan salah satu instrumen investasi di Indonesia. Pasar modal adalah jenis pasar abstrak yang di dalamnya memperjualbelikan dana-dana jangka menengah dan panjang, yaitu jangka satu tahun atau lebih (Widoatmodjo, 2008).

Sedangkan pasar modal syariah ialah pasar yang diharapkan memiliki fungsi yang sama dengan pasar modal konvensional tetapi dalam pasar modal syariah tidak mengandung unsur riba dan menerapkan prinsip-prinsip syariah yang mencerminkan keadilan dan juga pemerataan dalam distibusi keuntungannya (Peristiwo, 2016; Soemitra, 2014). Prinsip-prinsip syariah yang dimaksud adalah prinsip yang berdasarkan syariah Islam yang ditetapkan oleh DSN-MUI melalui Fatwa (Umar \& Zuhri, 2019). Pasar modal berperan penting dalam membangun perekonomian suatu negara. Melalui pasar modal para investor baik badan usaha maupun individu dapat berinvestasi di pasar modal. Selain itu, pengusaha juga dapat memperoleh pinjaman modal untuk membangun maupun mengembangkan usahanya (Saputra, 2018).

Menurut Mubarok (2018), perkembangan pasar modal syariah membutuhkan peranan dari berbagai macam pihak, salah satunya adalah mahasiswa PTKIN yang mana berbasis Islam. Berinvestasi sejak dini atau sejak mahasiswa merupakan salah satu prinsip investasi yang disebutkan oleh Warren Buffett (dalam Heller, 2003). Mahasiswa yang memiliki bekal pembelajaran dalam perkuliahan dapat menerapkannya dalam praktik nyata yaitu dengan berinvestasi. Hal tersebut menjadikan mahasiswa merupakan individu yang berpotensi untuk berinvestasi (Wibowo \& Purwohandoko, 2019).

Pada dasarnya mahasiswa sudah memiliki minat berinvestasi di pasar modal syariah. Namun terdapat beberapa kendala yang dihadapi terutama oleh investor pemula (Darmawan et al., 2019). Beberapa diantaranya yaitu religiusitas, pengetahuan terkait investasi, manfaat yang diperoleh dari investasi dan juga modal. Religiuitas merupakan keberagaman sisi maupun dimensi yang bukan hanya tentang beribadah melainkan berbagai aktivitas lainnya. Religius menurut Islam adalah menjalankan ajaran agama secara menyeluruh, dari segi pengetahuan, keyakinan, praktik serta penghayatan atas agama (Nabilah \& Hartutik, 2020). Tingkat religiusitas dapat memengaruhi minat seorang mahasiswa untuk melakukan investasi di pasar modal syariah karena adanya pengaruh prinsip-prinsip keislamannya. Tingkat religiusitas yang baik mampu membuat mahasiswa lebih memilih berinvestasi di pasar modal syariah daripada pasar modal konvensional.

Menurut Zulchayra et al. (2020) pengetahuan adalah sebuah informasi yang didapat atau dimengerti setelah melihat, menyaksikan dan mengalami suatu hal. Pengetahuan tentang investasi diantaranya pengetahuan tentang pasar modal, jenis instrumen investasi, tingkat keuntungan dan tingkat risiko. Pengetahuan dapat memengaruhi minat seorang mahasiswa dalam berinvestasi. Jika seorang mahasiswa tidak mengetahui terkait investasi dapat membuat mahasiswa tidak tertarik dengan investasi. Pengetahuan tentang manfaat juga memengaruhi minat mahasiswa dalam berinvestasi. Manfaat adalah kelebihan atau keuntungan yang diperoleh ketika berinvestasi. Seorang mahasiswa yang mengetahui bahwa investasi itu bermanfaat dan berdampak positif untuk finansial dimasa depan tentu akan membuat mahasiswa berminat untuk investasi. 


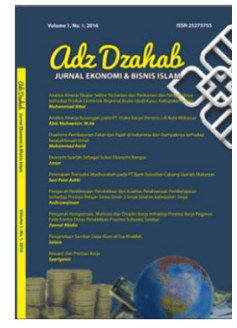

Adz Dzahab

Jurnal Ekonomi dan Bisnis Islam

Volume 6, No. 1, 2021

ISSN (print) : 2527-5755

ISSN (online) : 2751-1905

Homepage : http://journal.iaimsinjai.ac.id/index.php/adz-dzahab

Menurut Agestina et al. (2020), modal minimum investasi adalah setoran modal pertama dalam berinvestasi. Modal minimum investasi menjadi salah satu yang dipertimbangkan dalam berinvestasi. Semakin kecil modal awal yang dikeluarkan maka calon investor terutama untuk pemula akan semakin tertarik.

Berbagai hasil penelitian menyatakan bahwa terdapat beberapa faktor yang memengaruhi minat masyarakat dan mahasiswa untuk berinvestasi. Hasil penelitian yang mengungkapkan bahwa pengetahuan investasi berpengaruh secara positif dan signifikan terhadap minat investasi (Darmawan et al., 2019; Pajar \& Pustikaningsih, 2017). Artinya, semakin luas tingkat pengetahuan investasi yang dimiliki seseorang, maka semakin tinggi pula minat untuk berinvestasi. Lain halnya dengan pernyataan Malik (2017) yang dalam penelitiannya, pengetahuan investasi tidak memiliki pengaruh signifikan terhadap minat berinvestasi.

Selanjutnya, Agestina et al. (2020) mengungkapkan bahwa modal minimal investasi berpengaruh pada minat berinvestasi. Sedangkan Saputra (2018) dalam penelitiannya, mengatakan bahwa modal minimum investasi tidak berpengaruh siginfikan terhadap minat mahasiswa untuk berinvestasi di pasar modal. Sedangkan, manfaat investasi juga dapat memengaruhi minat mahasiswa dalam berinvestasi secara signifikan (Aditama \& Nurkhin, 2020; Saputra, 2018).

\section{Metode Penelitian}

\subsection{Jenis Penelitian}

Studi ini merupakan jenis studi/penelitian kuantitatif yang bertujuan untuk melakukan analisis terhadap determinan minat mahasiswa untuk menginvestasikan uangnya di pasar modal syariah. Mengenai variabel independen yang digunakan yaitu religiusitas, pengetahuan, manfaat dan modal minimum investasi, adapun variabel dependen yang dipakai adalah minat berinvestasi di pasar modal syariah. Penelitian ini memakai data primer yang didapatkan dari hasil penyebaran daftar pernyataan tertulis (kuesioner) dan menggunakan data sekunder dengan maksud untuk memperkuat gagasan yang dihimpun dari artikel-artikel hasil penelitian, situs website serta sumber-sumber bacaan yang sudah ada.

\subsection{Populasi dan Sampel}

Populasi ialah subjek/objek yang memiliki karakteristik dan kuantitas khusus yang dipilih peneliti untuk dikaji dan dibuat kesimpulan/generalisasi terhadap karakteristiknya (Siyoto \& Sodik, 2015). Populasi dalam penelitian ini yaitu mahasiswa IAIN Salatiga yang jumlahnya sebanyak 14.657 orang. Oleh sebab itu, untuk menentukan ukuran sampelnya menggunakan rumus Slovin (Radjab \& Jam'an, 2017). Secara matematis dituliskan sebagai berikut:

$$
n=\frac{N}{N e^{2}+1}=\frac{14.657}{14.657(0.1)^{2}+1}=99,32
$$

Setelah dihitung dengan menggunakan rumus di atas, dihasilkan jumlah sampel sebanyak 99,32 yang kemudian dibulatkan menjadi 100 responden. Berikutnya dalam menentukan sampel pada penelitian ini menggunakan metode purposive sampling, yaitu metode menyeleksi sekelompok subjek yang didasarkan atas kriteria tertentu dan dipandang mempunyai sangkut paut yang kuat dengan ciri dari populasi yang sudah diketahui sebelumnya (Syahrum \& Salim, 2012). Teknik ini dilakukan dengan cara membagikan kuesioner yang disertai keterangan berikut:

a. Mahasiswa/i S1 IAIN Salatiga tahun angkatan 2016, 2017, 2018, 2019 dan 2020.

b. Memiliki Kartu Tanda Penduduk (KTP). 


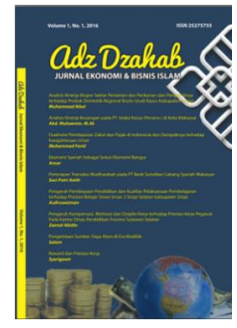

Adz Dzahab

Jurnal Ekonomi dan Bisnis Islam

Volume 6, No. 1, 2021

ISSN (print) : 2527-5755

ISSN (online) : 2751-1905

Homepage : http://journal.iaimsinjai.ac.id/index.php/adz-dzahab

\subsection{Teknik Pengumpulan Data}

Dalam penelitian ini teknik pengumpulan data dilakukan dengan menyebarkan angket berbasis web dan studi dokumentasi. Menurut Hardani et al. (2020) kuesioner berbasis web yaitu kuesioner yang akan diterima responden melalui media aplikasi setelahnya pengisian dilakukan pada alamat situs yang telah disediakan. Dalam penelitian ini kuesioner dibagikan kepada 100 responden. Berkaitan dengan itu, pengumpulan data dokumentasi juga dilakukan dengan menghimpun literatur-literatur yang relevan baik dari buku, artikel penelitian, maupun situs webite terpercaya.

\subsection{Metode Analisis Data}

Data dalam penelitian ini dianalisis dengan beberapa tahap. Pertama ialah uji validitas dan reliabilitas. Setelah data valid dan reliabel, analisis kedua yaitu uji asumsi klasik yang meliputi uji normalitas, uji multikolinieritas dan uji heteroskedastisitas. Tahap ketiga ialah analisis regresi linier berganda. Analisis regresi sendiri merupakan metode yang dipakai untuk menguji secara matematis hubungan antara satu atau lebih variabel independen dengan variabel dependen (Bawono \& Shina, 2018). Secara umum model analisis regresi linier berganda adalah sebagai berikut:

$$
\mathrm{Y}=\beta_{0}+\beta_{1} \mathrm{X}_{1}+\beta_{2} \mathrm{X}_{2}+\ldots \ldots \ldots \ldots \ldots . .+\beta_{\mathrm{p}} \mathrm{X}_{\mathrm{p}}+\varepsilon
$$

Rumus tersebut kemudian dikonversi ke dalam penelitian ini, sehingga akan menjadi seperti berikut:

Dimana:

$$
\mathrm{MB}=\beta_{0}+\beta_{1} \mathrm{R}+\beta_{2} \mathrm{P}+\beta_{3} \mathrm{M}+\beta_{4} \mathrm{MMI}+\varepsilon
$$

$$
\begin{array}{ll}
\mathrm{MB} & =\text { Minat Berinvestasi } \\
\beta_{0} & =\text { Konstanta } \\
\beta_{1} \beta_{2} \beta_{3} \beta_{4} & =\text { Koefisien } \\
\mathrm{R} & =\text { Religiusitas } \\
\mathrm{P} & =\text { Pengetahuan } \\
\mathrm{M} & =\text { Manfaat } \\
\mathrm{MMI} & =\text { Modal Minimum Investasi } \\
\varepsilon & =\text { Error Term }
\end{array}
$$

Analisis terakhir pada penelitian ini yaitu melakukan uji hipotesis baik untuk pengaruh secara individual (parsial) maupun bersama-sama (simultan).

\section{Hasil dan Pembahasan}

\subsection{Hasil Uji Validitas}

Pengujian validitas dilakukan guna mengetahui apakah item pernyataan yang diajukkan dalam angket valid atau tidak. Instrumen yang mampu mengukur variabel yang akan diukur, maka dapat disimpulkan bahwa instrumen tersebut telah valid (Rusman, 2015). Berikut hasil uji validitas: 


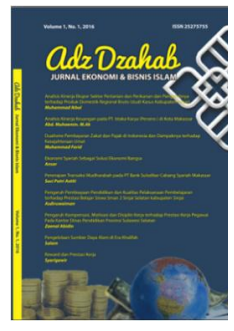

Adz Dzahab

Jurnal Ekonomi dan Bisnis Islam

Volume 6, No. 1, 2021

ISSN (print) : 2527-5755

ISSN (online) : 2751-1905

Homepage : http://journal.iaimsinjai.ac.id/index.php/adz-dzahab

Tabel 1. Uji Validitas

\begin{tabular}{|c|c|c|c|c|}
\hline Variabel & Item & $\mathbf{r}_{\text {hitung }}$ & $\mathbf{r}_{\text {tabel }}$ & Keterangan \\
\hline \multirow{8}{*}{ Religiusitas (X1) } & $\mathrm{R} 1$ & 0,393 & \multirow{8}{*}{0,196} & Valid \\
\hline & $\mathrm{R} 2$ & 0,205 & & Valid \\
\hline & $\mathrm{R} 3$ & 0,731 & & Valid \\
\hline & $\mathrm{R} 4$ & 0,690 & & Valid \\
\hline & R5 & 0,784 & & Valid \\
\hline & R6 & 0,789 & & Valid \\
\hline & R7 & 0,740 & & Valid \\
\hline & $\mathrm{R} 8$ & 0,390 & & Valid \\
\hline \multirow{8}{*}{ Pengetahuan (X2) } & P1 & 0,296 & \multirow{8}{*}{0,196} & Valid \\
\hline & $\mathrm{P} 2$ & 0,631 & & Valid \\
\hline & $\mathrm{P} 3$ & 0,610 & & Valid \\
\hline & $\mathrm{P} 4$ & 0,608 & & Valid \\
\hline & P5 & 0,527 & & Valid \\
\hline & P6 & 0,548 & & Valid \\
\hline & P7 & 0,482 & & Valid \\
\hline & P8 & 0,513 & & Valid \\
\hline \multirow{8}{*}{ Manfaat (X3) } & M1 & 0,774 & \multirow{8}{*}{0,196} & Valid \\
\hline & M2 & 0,779 & & Valid \\
\hline & M3 & 0,759 & & Valid \\
\hline & M4 & 0,631 & & Valid \\
\hline & M5 & 0,791 & & Valid \\
\hline & M6 & 0,765 & & Valid \\
\hline & M7 & 0,711 & & Valid \\
\hline & M8 & 0,627 & & Valid \\
\hline \multirow{8}{*}{$\begin{array}{l}\text { Modal Minimum } \\
\text { Investasi (X4) }\end{array}$} & MMI1 & 0,543 & \multirow{8}{*}{0,196} & Valid \\
\hline & MMI2 & 0,776 & & Valid \\
\hline & MMI3 & 0,738 & & Valid \\
\hline & MMI4 & 0,802 & & Valid \\
\hline & MMI5 & 0,740 & & Valid \\
\hline & MMI6 & 0,817 & & Valid \\
\hline & MMI7 & 0,733 & & Valid \\
\hline & MMI8 & 0,711 & & Valid \\
\hline \multirow{8}{*}{ Minat Berinvestasi (Y) } & MB1 & 0,509 & \multirow{8}{*}{0,196} & Valid \\
\hline & MB2 & 0,605 & & Valid \\
\hline & MB3 & 0,707 & & Valid \\
\hline & MB4 & 0,709 & & Valid \\
\hline & MB5 & 0,721 & & Valid \\
\hline & MB6 & 0,770 & & Valid \\
\hline & MB7 & 0,676 & & Valid \\
\hline & MB8 & 0,682 & & Valid \\
\hline
\end{tabular}

Sumber: Data primer diolah, 2021. 


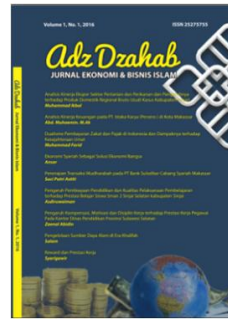

Adz Dzahab

Jurnal Ekonomi dan Bisnis Islam

Volume 6, No. 1, 2021

ISSN (print) : 2527-5755

ISSN (online) : 2751-1905

Homepage : http://journal.iaimsinjai.ac.id/index.php/adz-dzahab

Mengacu pada tabel hasil uji validitas di atas, dapat ditarik kesimpulan bahwa seluruh item pernyataan ( 40 item) dari kelima variabel telah valid, hal tersebut dikarenakan seluruh item memiliki nilai $r_{\text {hitung }}>r_{\text {tabel }}\left(r_{\text {hitung }}>0,196\right)$. Karena seluruh item telah dinyatakan valid, sehingga dapat digunakan untuk analisis lebih lanjut.

\subsection{Hasil Uji Reliabilitas}

Setelah semua item yang dinyatakan valid, pengujian berikutnya yaitu uji reliabilitas. Berikut untuk hasil pengujiannya:

Tabel 2. Uji Reliabilitas

\begin{tabular}{lccc}
\hline \multicolumn{1}{c}{ Variabel } & $\begin{array}{c}\text { Cronbach's } \\
\text { Alpha }\end{array}$ & Koefisien & Keterangan \\
\hline Religiusitas (X1) & 0,775 & & Reliabel \\
Pengetahuan (X2) & 0,611 & & Reliabel \\
Manfaat (X3) & 0,870 & 0.60 & Reliabel \\
Modal Minimum Investasi (X4) & 0,873 & & Reliabel \\
Minat Berinvestasi (Y) & 0,827 & & Reliabel \\
\hline
\end{tabular}

Sumber: Data primer diolah, 2021.

Suatu variabel dapat dikatakkan reliabel jika nilai Cronbach's Alpha di atas 0,60 (Yuliardi \& Nuraeni, 2017). Seperti yang terlihat pada tabel 2, mengindikasikan bahwa kelima variabel yang digunakan telah reliabel karena memiliki nilai Cronbach's Alpha > 0,60 . Karena data telah valid dan reliabel, maka dapat dipakai untuk dilakukan uji-uji statistik selanjutnya.

\subsection{Statistik Deskriptif}

Tabel 3. Statistik Deskriptif

\begin{tabular}{lccccc}
\hline & $\mathrm{N}$ & Minimum & Maximum & Mean & Std. Deviation \\
\hline Religiusitas & 100 & 29 & 40 & 36.13 & 3.021 \\
Pengetahuan & 100 & 27 & 40 & 32.80 & 3.396 \\
Manfaat & 100 & 25 & 40 & 35.14 & 3.553 \\
Modal Minimum & 100 & 24 & 40 & 33.26 & 4.559 \\
Investasi & 100 & 25 & 40 & 33.39 & 4.202 \\
Minat Berinvestasi & 100 & & & & \\
Valid N (listwise) & & & & &
\end{tabular}

Sumber: Data primer diolah, 2021.

Menilik tabel analisis statistik deskriptif di atas, diketahui bahwa nilai tertinggi, terendah, rata-rata dan standar deviasi dari variabel minat berinvestasi secara berturut-turut yaitu 40,00;25,00;33,39;4,202. Berdasarkan nilai rata-rata yang diperoleh, dapat disimpulkan bahwa minat mahasiswa dalam berinvestasi di pasar modal syariah cenderung tinggi. Sedangkan untuk variabel religiusitas memiliki nilai tertinggi, terendah, rata-rata dan standar deviasi secara berturut-turut yaitu 40,$00 ; 29,00 ; 36,13 ; 3,021$. Berdasarkan nilai rata-rata yang diperoleh bahwa religisuitas tergolong dalam kategori baik.

Nilai tertinggi, terendah, rata-rata dan standar deviasi dari variabel pengetahuan secara berturut-turut yaitu 40,$00 ; 27,00 ; 32,80 ; 3,396$. Berdasarkan nilai rata-rata yang diperoleh, dapat dikatakan bahwa pengetahuan investasi mahasiswa tergolong dalam kategori tinggi. Kemudian untuk variabel manfaat memiliki nilai tertinggi, terendah, ratarata dan standar deviasi secara berturut-turut yaitu sebesar 40,00;25,00;35,14;3,553. Berdasarkan nilai rata-rata yang diperoleh, menunjukkan bahwa manfaat dalam kategori 


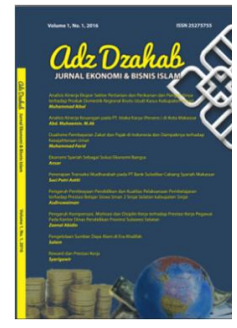

Adz Dzahab

Jurnal Ekonomi dan Bisnis Islam

Volume 6, No. 1, 2021

ISSN (print) : 2527-5755

ISSN (online) : 2751-1905

Homepage : http://journal.iaimsinjai.ac.id/index.php/adz-dzahab

tinggi. Sedangkan untuk variabel modal minimum investasi memiliki nilai tertinggi, terendah, rata-rata dan standar deviasi secara berturut-turut sebesar 40,00;24,00;33,26; 4,559 . Berdasarkan nilai rata-rata yang diperoleh dapat dikatakan bahwa modal minimum investasi tergolong dalam kategori baik.

\subsection{Hasil Uji Asumsi Klasik Uji Normalitas}

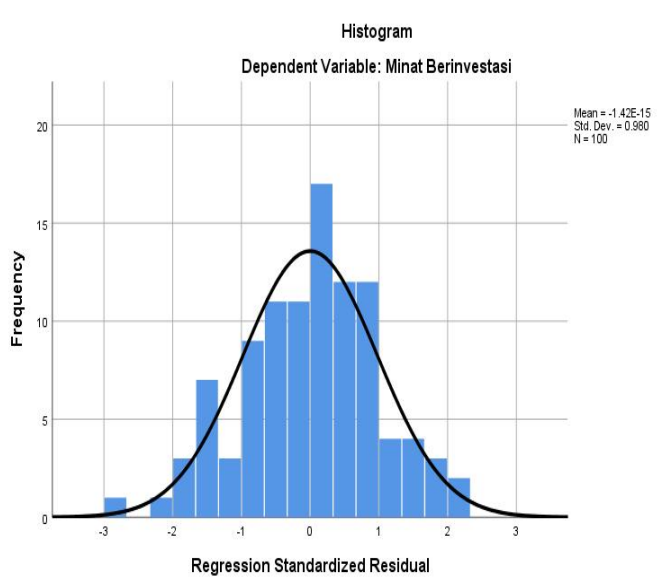

Gambar 1. Histogram

Sumber: Data primer diolah, 2021

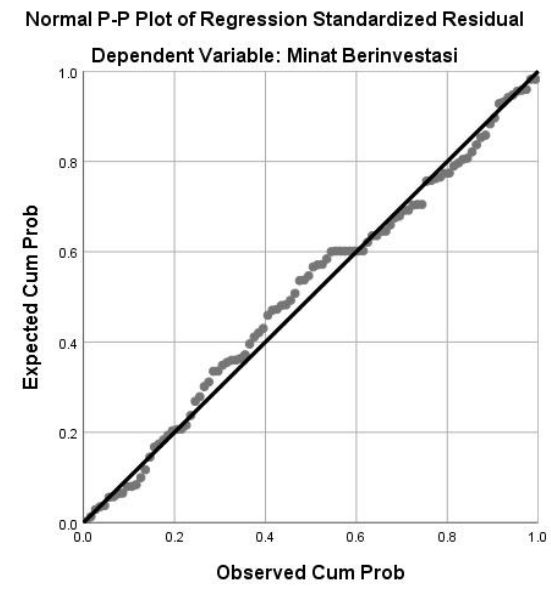

Gambar 2. Normal P-P Plot

Sumber: Data primer diolah, 2021

Tabel 4. Uji Kolmogorov-Smirnov

\begin{tabular}{llr}
\hline & & Unstandardized Residual \\
\hline $\mathrm{N}$ & & 100 \\
\hline Normal Parameters & Mean & 0,0000000 \\
& Std. Deviation & 2,77863035 \\
Most Extreme & Absolute & 0,068 \\
Differences & Positive & 0,041 \\
& Negative & $-0,068$ \\
Test Statistic & & 0,068 \\
Asymp. Sig. (2-tailed) & & 0,200 \\
\hline
\end{tabular}

Sumber: Data primer diolah, 2021.

Sebelum dilanjutkan pada tahap uji hipotesis, data harus memenuhi salah satu uji asumsi yaitu uji normalitas. Dimana pengujian tersebut bertujuan untuk mengidentifikasi apakah variabel pengganggu (residual) dalam regresi telah terdistribusi normal (Ghozali, 2018). Cara untuk mengetahui apakah data telah normal atau tidak yaitu dengan melihat grafik histogram dan grafik normal plot. Selain itu, untuk lebih meyakinkan hasil analisis grafik, pengujian normalitas dapat dilakukan secara statistik yaitu menggunakan uji K-S (Kolmogorov-Smirnov).

Berdasarkan grafik histogram (gambar 1) menampilkan grafik seperti lonceng dan grafik normal plot (gambar 2) yang memperlihatkan titik-titiknya menyebar megikuti garis diagonalnya. Dengan demikian berdasarkan grafik normalitas, data telah berdistribusi normal. Namun, analisis grafik dinilai terlalu lemah sehingga perlu dilakukan pengujian secara statistik dengan menggunakan uji Kolmogorov-Smirnov. Berdasrkan tabel 4 (uji KS) dapat disimpulkan bahwa data telah berdistribusi normal, karena nilai signifikansi 0,200 $>0,05$. 


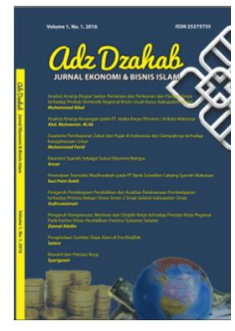

Adz Dzahab

Jurnal Ekonomi dan Bisnis Islam

Volume 6, No. 1, 2021

ISSN (print) : 2527-5755

ISSN (online) : 2751-1905

Homepage : http://journal.iaimsinjai.ac.id/index.php/adz-dzahab

Uji Multikolinieritas

Tabel 5. Uji Multikolinieritas

\begin{tabular}{llcc}
\hline & & \multicolumn{2}{c}{ Collinearity Statistics } \\
\cline { 3 - 4 } Model & & Tolerance & VIF \\
\hline 1 & (Constant) & 0,763 & 1,311 \\
& Religiusitas & 0,570 & 1,756 \\
& Pengetahuan & 0,536 & 1,866 \\
& Manfaat & 0,523 & 1,912 \\
& Modal Minimum & & \\
\hline
\end{tabular}

Sumber: Data primer diolah, 2021.

Salah satu asumsi yang juga harus dipenuhi sebelum dilakukan analisis hipotesis yaitu data harus terbebas dari masalah multikolinieritas. Uji multikolinieritas bertujuan untuk mendeteksi antara variabel bebas satu dengan yang lain berkorelasi tinggi atau tidak (Purnomo, 2019). Multikolinieritas secara umum menggunakan nilai tolerance dan nilai variance inflation factor (VIF). Dapat dikatakan terbebas dari gejala multikolinieritas apabila nilai tolerance $>0,1$ dan VIF $<10$. Sebagaimana hasil uji multikolinieritas (tabel 5) menunjukkan bahwa data tidak terjadi masalah multikolinieritas, karena variabelvariabel yang digunakan secara statistik telah sesuai dengan teori statistik uji multikolinieritas yaitu memiliki nilai tolerance $>0,1$ dan nilai $\mathrm{VIF}<10$.

\section{Uji Heteroskedastisitas}

Tabel 6. Uji Heteroskedastisitas (Metode Park)

\begin{tabular}{llcc}
\hline Model & & $\mathrm{t}$ & Sig. \\
\hline 1 & (Constant) & 0,587 & 0,559 \\
& Religiusitas & $-0,074$ & 0,942 \\
& Pengetahuan & $-1,647$ & 0,103 \\
& Manfaat & 1,278 & 0,204 \\
& Modal Minimum & 0,051 & 0,960 \\
& Investasi & & \\
\hline
\end{tabular}

Sumber: Data primer diolah, 2021.

Selain data harus berdistribusi normal dan terbebas dari gejala multikolinieritas, asumsi yang harus dipenuhi sebelum data digunakan untuk pengujian selanjutnya ialah data harus terhindar dari gejala heteroskedastisitas. Dalam penelitian ini, metode park digunakan untuk menguji heteroskedastisitas. Dalam metode park, pola yang digunakan ialah logaritma bukan linier, dan dapat dikatakan tidak terjangkit masalah heteroskedastisitas jika nilai signifikansi $>0,05$ (Muis, 2017). Dari hasil pengujian (tabel 6), dapat disimpulkan bahwa tidak terdapat masalah heteroskedastisitas karena seluruh variabel memiliki nilai signifikansi $>0,05$. 


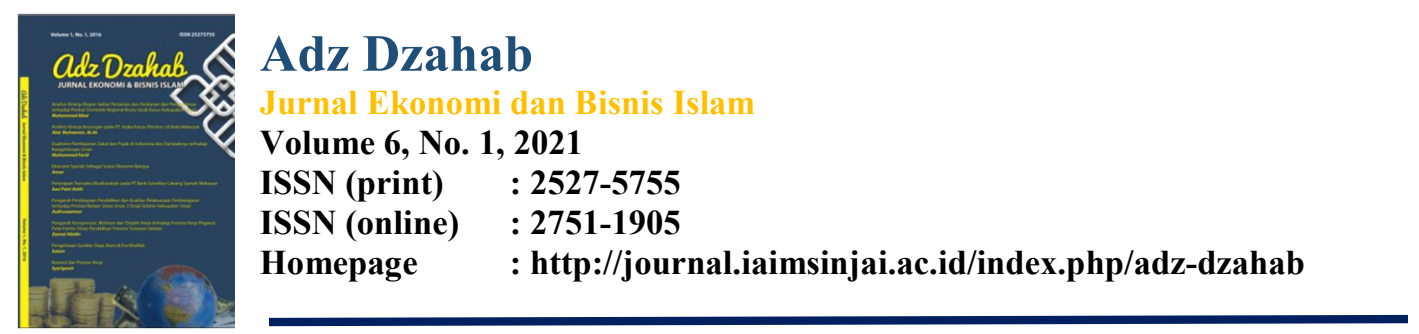

3.5. Hasil Analisis Regresi Linier Berganda

Tabel 7. Analisis Regresi Linier Berganda

\begin{tabular}{|c|c|c|c|c|c|}
\hline \multirow[b]{2}{*}{ Model } & \multicolumn{2}{|c|}{$\begin{array}{l}\text { Unstandardized } \\
\text { Coefficients }\end{array}$} & \multirow{2}{*}{$\begin{array}{c}\begin{array}{c}\text { Standardized } \\
\text { Coefficients }\end{array} \\
\text { Beta }\end{array}$} & \multirow[b]{2}{*}{$\mathrm{t}$} & \multirow[b]{2}{*}{ Sig. } \\
\hline & $\mathrm{B}$ & Std. Error & & & \\
\hline (Constant) & 3,000 & 3,916 & & 0,766 & 0,446 \\
\hline Religiusitas & 0,001 & 0,108 & 0,001 & 0,012 & 0,991 \\
\hline Pengetahuan & 0,268 & 0,111 & 0,217 & 2,409 & 0,018 \\
\hline Manfaat & 0,186 & 0,110 & 0,158 & 1,701 & 0,092 \\
\hline Modal Minimum Investasi & 0,451 & 0,086 & 0,489 & 5,216 & 0,000 \\
\hline
\end{tabular}

Sumber: Data primer diolah, 2021.

Tabel di atas merupakan hasil analisis regresi linier berganda, sehingga dapat dituliskan persamaan regresinya yang mengacu pada kolom B pada tabel diatas:

$$
\mathrm{MB}=3,000+0,001 \mathrm{R}+0,268 \mathrm{P}+0,186 \mathrm{M}+0,451 \mathrm{MMI}
$$

Dari persamaan tersebut didapatkan nilai $\beta_{0}$ (konstanta) sebesar 3,000 yang memiliki arti bahwa jika religiusitas, pengetahuan, manfaat dan modal minimum investasi bernilai tetap atau konstan, maka minat berinvestasi di pasar modal syariah sebesar 3,000. Kemudian, variabel religiusitas $\left(\beta_{1}\right)$ diperoleh koefisien sebesar 0,001 yang artinya bahwa jika religiusitas meningkat sebesar satu persen sedangkan pengetahuan, manfaat dan modal minimum investasi bernilai tetap, maka minat untuk melakukan investasi di pasar modal syariah meningkat sebesar 0,001 . Berikutnya, variabel pengetahuan $\left(\beta_{2}\right)$ memiliki koefisien sebesar 0,268 yang berarti apabila pengetahuan bertambah satu persen sedangkan religiusitas, manfaat dan modal minimum investasi bernilai konstan, maka minat untuk melakukan investasi di pasar modal syariah akan meningkat sebesar 0,268.

Selanjutnya, variabel manfaat $\left(\beta_{3}\right)$ diperoleh koefisien sebesar 0,186 yang artinya jika manfaat bertambah sebesar satu persen sedangkan religiusitas, pengetahuan dan modal minimum investasi bernilai tetap/konstan, maka minat untuk melakukan investasi di pasar modal syariah akan mengalami peningkatan sebesar 0,186 . Sedangkan untuk nilai koefisien variabel modal minimum investasi $\left(\beta_{4}\right)$ sebesar 0,451 yang berarti apabila modal minimum investasi meningkat sebesar satu ribuan sedangkan religisuitas, pengetahuan dan manfaat bernilai konstan, maka minat berinvestasi di pasar modal syariah akan meningkat sebesar 0,451 . 


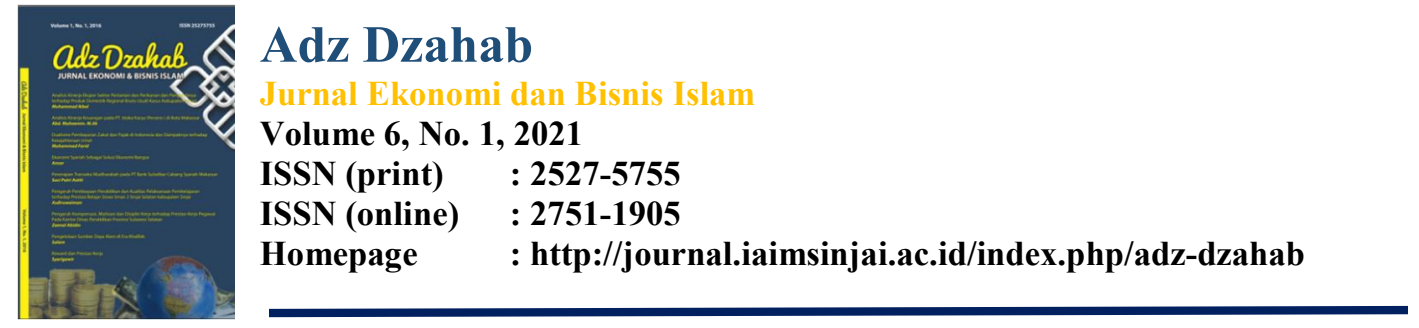

\subsection{Hasil Uji Hipotesis}

Tabel 8. Uji Hipotesis

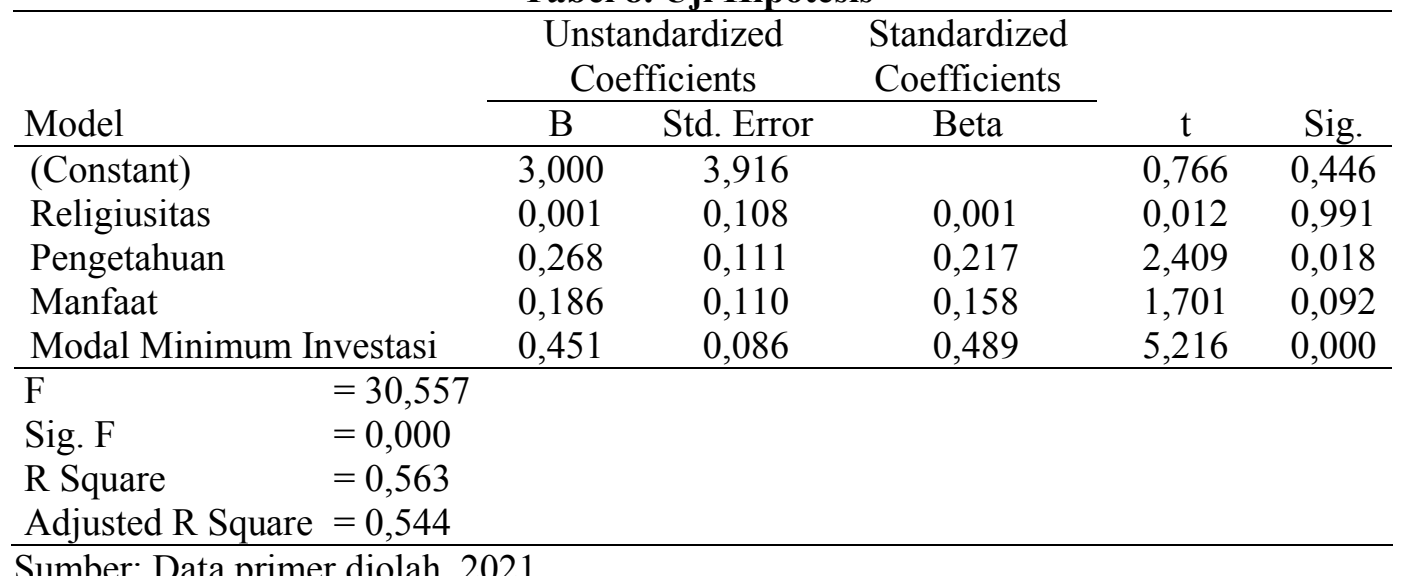

Analisis uji hipotesis dilakukan secara dua tahap, tahap pertama uji hipotesis secara parsial dengan menggunakan uji statistik t, tahap kedua uji hipotesis secara simultan dengan menggunakan uji statistik F. Merujuk pada tabel 8, untuk variabel religiusitas $\left(\mathrm{X}_{1}\right)$ mendapat nilai signifikansi sebesar 0,991 >0,05. Sehingga dapat disimpulkan bahwa religiusitas tidak memiliki pengaruh signifikan terhadap minat berinvestasi. Sedangkan nilai signifikansi variabel pengetahuan $\left(\mathrm{X}_{2}\right)$ diperoleh sebesar $0,018<0,05$. Artinya, pengetahuan secara signifikan berpengaruh terhadap minat berinvestasi.

Berikutnya yaitu variabel manfaat $\left(\mathrm{X}_{3}\right)$ yang mendapat nilai signifikansi sebesar $0,092>0,05$. Dengan demikian, variabel manfaat tidak memiliki pengaruh signifikan terhadap minat berinvestasi. Selanjutnya, nilai signifikansi variabel modal minimum investasi $\left(\mathrm{X}_{4}\right)$ diperoleh sebesar $0,000<0,05$. Maka dapat dikatakan bahwa variabel modal minimum investasi secara signifikan berpengaruh terhadap minat berinvestasi di pasar modal syariah.

Sedangkan secara bersama-sama keempat variabel independen (religiusitas, pengetahuan, manfaat dan modal minimum investasi) berpengaruh signifikan terhadap minat berinvestasi di pasar modal syariah. Hal demikian dapat diketahui dari nilai signifikansi $\mathrm{F}<$ alpha $(0,000<0,05)$. Kemudian untuk kemampuan variabel independen dalam memengaruhi variabel dependen dapat diketahui dari hasil $\mathrm{R}^{2}(R$ Square) yang diperoleh nilai sebesar 0,563 atau $56,3 \%$. Yang berarti variasi variabel bebas dalam model mampu memengaruhi variabel terikatnya sebesar $56,3 \%$, sedangkan selebihnya yaitu $43,7 \%$ dipengaruhi oleh variabel yang tidak dimasukkan ke dalam model.

\subsection{Pembahasan}

Hasil yang diperoleh dari analisis data yang dilakukan menghasilkan bahwa religiusitas terhadap minat berinvestasi di pasar modal syariah memiliki pengaruh tidak signifikan. Hal ini mengindikasikan bahwa semakin baik religiusitas seseorang maka akan mendororng minatnya dalam berinvestasi di pasar modal syariah tetapi tidak signifikan. Meskipun secara analisis deskriptif rata-rata tingkat religiusitas mahasiswa termasuk pada kategori baik, namun tidak menentukan minat seorang mahasiswa dalam melakukan investasi di pasar modal syariah. Karena tingkat pemahaman religiusitas atau praktik keagamaan antara satu orang dengan yang lainnya berbeda-beda, sehingga religiusitas tidak serta-merta memengaruhi minat mahasiswa untuk berinvestasi di pasar modal syariah. Hasil temuan tersebut mengonfirmasi studi yang dilakukan Rosyidah \& Lestari (2013) dan 


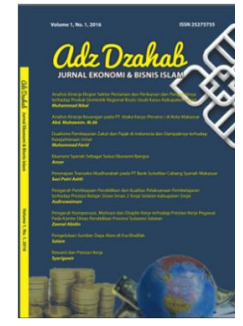

Adz Dzahab

Jurnal Ekonomi dan Bisnis Islam

Volume 6, No. 1, 2021

ISSN (print) : 2527-5755

ISSN (online) : 2751-1905

Homepage : http://journal.iaimsinjai.ac.id/index.php/adz-dzahab

Fauziah (2019) yang dalam penelitiannya juga menemukan bahwa religiusitas tidak memiliki pengaruh signifikan terhadap minat investasi. Akan tetapi, hasil ini tidak mendukung penelitian Nabilah \& Hartutik (2020) yang mengungkapkan bahwa religiusitas dapat memengaruhi secara signifikan minat seseorang untuk berinvestasi di pasar modal syariah.

Berikutnya, dari hasil estimasi yang dilakukan memberikan informasi bahwa secara positif dan signifikan pengetahuan memengaruhi minat mahasiswa dalam berinvestasi di pasar modal syariah. Artinya semakin tinggi tingkat pemahaman atau pengetahuan yang dimiliki oleh mahasiswa mengenai investasi secara syariah maka minat untuk melakukan investasi di pasar modal syariah pun akan meningkat. Hasil ini mendukung Sugianto et al. (2019) dan Hasanah \& Kurnia (2019) yang dalam studinya mengungkapkan bahwa pengetahuan secara positif dan signifikan berpengaruh terhadap minat berinvestasi. Namun, hasil ini tidak sependapat dengan Malik (2017) yang mengungkapkan bahwa pengetahuan tidak berpengaruh terhadap minat berinvestasi di pasar modal syariah.

Selanjutnya, hasil yang diperoleh berdasarkan analisis yang telah dilakukan yaitu manfaat investasi terhadap minat berinvestasi berpengaruh tidak signifikan. Artinya bahwa mahasiswa menganggap bahwa berinvestasi secara syariah dapat memberikan manfaat akan tetapi tidak selalu memengaruhi minatnya untuk melakukan investasi di pasar modal syariah. Temuan ini selaras dengan Wulandari et al. (2017) yang dalam penelitiannya juga menemukan bahwa manfaat berpengaruh tidak signifikan terhadap minat berinvestasi. Akan tetapi bertolak belakang dengan hasil studi Oktavia et al. (2020) yang menemukan bahwa manfaat secara signifikan berpengaruh terhadap minat berinvestasi.

Hasil analisis untuk variabel terakhir yaitu modal minimum investasi dapat dikatakan bahwa secara positif dan signifikan memengaruhi minat mahasiswa dalam berinvestasi. Yang berarti jika modal untuk melakukan investasi semakin terjangkau atau sedikit, maka minatnya untuk berinvestasi semakin tinggi. Hasil ini mengonfirmasi penelitian yang dilakukan Nisa \& Zulaika (2017), Wibowo \& Purwohandoko (2019) dan Haidir (2019) yang juga menemukan bahwa modal minimum investasi secara positif dan signifikan memengaruhi minat berinvestasi. Akan tetapi tidak sependapat dengan temuan Tandio et al. (2014) dan Aini et al. (2019) yang menyatakan bahwa modal minimum investasi tidak memengaruhi minat mahasiswa dalam melakukan investasi.

\section{Simpulan}

Berdasarkan penelitian yang telah dilakukan dapat ditarik beberapa kesimpulan. Pertama, religiusitas dan manfaat teridentifikasi berpengaruh tidak signifikan terhadap minat mahasiswa dalam berinvestasi di pasar modal syariah. Kedua, pengetahuan dan modal minimum investasi berpengaruh positif dan signifikan terhadap minat mahasiswa dalam berinvestasi di pasar modal syariah. Sedangkan, religiusitas, pengetahuan, manfaat dan modal minimum investasi secara bersama-sama berpengaruh signifikan terhadap minat mahasiswa dalam berinvestasi di pasar modal syariah.

Penelitian ini memberikan implikasi praktis bahwa instansi pendidikan khususnya IAIN Salatiga agar lebih masif memberikan pemahaman kepada mahasiswanya mengenai pentingnya berinvestasi sejak dini di pasar modal syariah. Selain itu, penelitian ini memiliki beberapa keterbatasan yaitu populasi yang dipilih hanya meliputi satu instansi dan metode analisis yang digunakan terlalu sederhana. Oleh karena itu, studi ini memberikan rekomendasi terhadap penelitian selanjutnya untuk dapat memperluas jumlah populasi, menambah jumlah variabel dan menggunakan teknik analisis data yang lebih kompleks seperti analisis jalur ataupun teknik analisis lainnya, sehingga dapat memberikan hasil yang lebih komprehensif. 


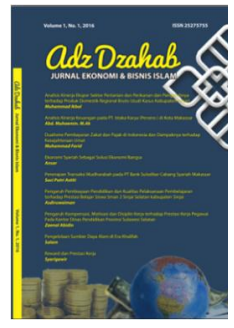

\section{Daftar Pustaka}

Aditama, R. R., \& Nurkhin, A. (2020). Pengaruh Pelatihan Pasar Modal terhadap Minat Investasi Mahasiswa di Pasar Modal dengan Pengetahuan Investasi dan Manfaat Investasi sebagai Variabel Intervening. Business and Accounting Education Journal, l(1), 27-42.

Agestina, N. I., Amin, M., \& Anwar, S. A. (2020). Analisis Pengaruh Modal Minimal, Pemahaman Investasi dan Teknologi Informasi terhadap Minat Mahasiswa Berinvestasi di Pasar Modal di Tinjau dari Perspektif Ekonomi Islam (Studi pada Mahasiswa Fakultas Ekonomi dan Bisnis Universitas Islam Malang). E-JRA, 9(1), $60-68$.

Aini, N., Maslichah, \& Junaidi. (2019). Pengaruh Pengetahuan dan Pemahaman Investasi, Modal Minimum Investasi, Return dan Motivasi Investasi terhadap Minat Mahasiswa Berinvestasi di Pasar Modal (Studi pada Mahasiswa Fakultas Ekonomi dan Bisnis Kota Malang). E-JRA, 8(5), 38-52.

Bawono, A., \& Shina, A. F. I. (2018). Ekonometrika Terapan: Untuk Ekonomi dan Bisnis Islam Aplikasi dengan Eviews. Salatiga: LP2M IAIN Salatiga.

BKPM. (2020). Realisasi Investasi Triwulan III Tahun 2020 Meningkat. https://www.bkpm.go.id/id/publikasi/siaran-pers/readmore/2408601/65201

Darmawan, A., Kurnia, K., \& Rejeki, S. (2019). Pengetahuan Investasi, Motivasi Investasi, Literasi Keuangan dan Lingkungan Keluarga Pengaruhnya terhadap Minat Investasi di Pasar Modal. Jurnal Ilmiah Akuntansi Dan Keuangan, 8(2), 44-56.

Fauziah, L. N. (2019). Analisis Pengaruh Tingkat Literasi Keuangan dan Religiusitas terhadap Keputusan Investasi Studi Pada Mahasiswa Fakultas Ekonomi UIN Maulana Malik Ibrahim Malang. Skripsi. UIN Maulana Malik Ibrahim.

Ghozali, I. (2018). Aplikasi Analisis Multivariat dengan Program IBM SPSS 25. Semarang: Badan Penerbit-Undip.

Haidir, M. S. (2019). Pengaruh Pemahaman Investasi, dengan Modal Minimal dan Motivasi terhadap Minat Mahasiswa Dalam Melakukan Investasi di Pasar Modal Syariah. Jurnal Istiqro: Jurnal Hukum Islam, Ekonomi Dan Bisnis, 5(2), 198-211.

Hardani, Andriani, H., Ustiawaty, J., Utami, E. F., Istiqomah, R. R., Fardani, R. A., Sukmana, D. J., \& Auliya, N. H. (2020). Metode Penelitian Kualitatif \& Kuantitatif. Yogyakarta: CV. Pustaka Ilmu Group.

Mubarok, F. K. (2018). Peran Sosialisasi dan Edukasi dalam Menumbuhkan Minat Investasi di Pasar Modal Syariah. Inovasi, 14(2), 113-122.

Muis, S. (2017). Matematika Ekonomi. Yogyakarta: Ekuilibria.

Nabilah, F., \& Hartutik. (2020). Pengaruh Pengetahuan, Religiusitas dan Motivasi Investasi terhadap Minat Berinvestasi Pasar Modal Syariah pada Komunitas Investor Saham Pemula. Taraadin, 1(1), 55-67.

Nisa, A., \& Zulaika, L. (2017). Pengaruh Pemahaman Investasi, Modal Minimal Investasi dan Motivasi terhadap Minat Mahasiswa Berinvestasi di Pasar Modal. Jurnal Penelitian Teori \& Terapan Akuntansi (PETA), 2(2), 22-35.

Oktavia, S. A., Mu'ayanah, R., \& Hana, K. F. (2020). Pengaruh Edukasi, Manfaat, Rekomendasi Pasar Modal Syariah terhadap Minat Berinvestasi Mahasiswa FEBI IAIN Kudus. BanKu: Jurnal Perbankan Dan Keuangan, 1(2), 75-84.

Pajar, R. C., \& Pustikaningsih, A. (2017). Pengaruh Motivasi Investasi dan Pengetahuan Investasi terhadap Minat Investasi di Pasar Modal Pada Mahasiswa FE UNY. Jurnal Profita: Kajian Ilmu Akuntansi, 5(1), 1-16.

Purnomo, A. K. (2019). Pengolahan Riset Ekonomi Jadi Mudah dengan IBM SPSS. 


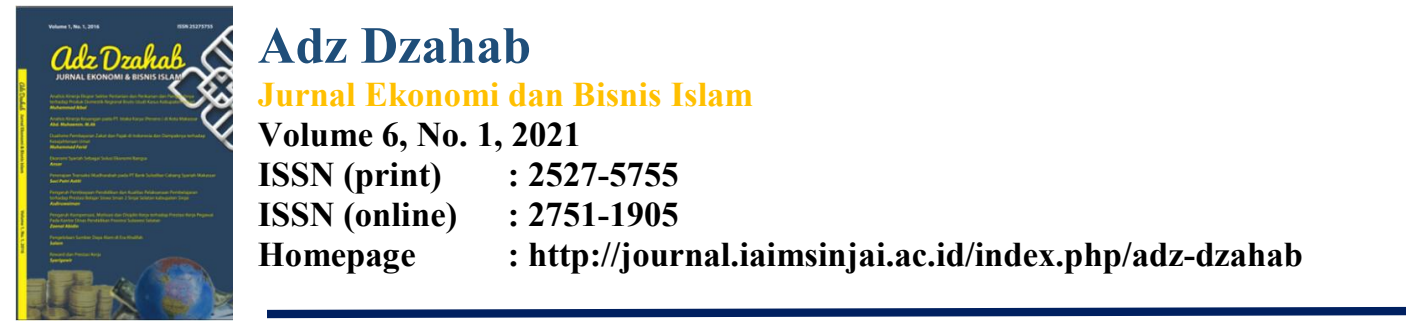

Surabaya: Jakad Publishing.

Radjab, E., \& Jam'an, A. (2017). Metode Penelitian Bisnis (1 ${ }^{\text {st }}$ ed.). Makassar: Lembaga Perpustakaan dan Penerbitan Universitas Muhammadiyah Makassar.

Rosyidah, S. M., \& Lestari, W. (2013). Religiusitas dan Persepsi Risiko dalam Pengambilan Keputusan Investasi Pada Perspektif Gender. Journal of Business and Banking, 3(2), 189-200.

Saputra, D. (2018). Pengaruh Manfaat, Modal, Motivasi dan Edukasi terhadap Minat dalam Berinvestasi di Pasar Modal. Future Jurnal Manajemen Dan Akuntansi, 5(2), 178190.

Sugianto, L. O., Ardiana, T. E., \& Santoso, S. (2019). Intrinsic Motivation and Knowledge Investment Toward Interest Lecturer Invest in Indonesia Stock Exchange. AFRE (Accounting and Financial Review), 2(2), 113-118.

Umar, A. U. A. Al, \& Zuhri, S. (2019). Pengaruh Manfaat, Pengetahuan dan Edukasi terhadap Minat Mahasiswa dalam Berinvestasi di Pasar Modal Syariah. Li Falah: Jurnal Studi Ekonomi Dan Bisnis Islam, 4(1), 129-138.

Wibowo, A., \& Purwohandoko. (2019). Pengaruh Pengetahuan Investasi, Kebijakan Modal Minimal Investasi, dan Pelatihan Pasar Modal terhadap Minat Investasi (Studi Kasus Mahasiswa FE Unesa yang Terdaftar di Galeri Investasi FE Unesa). Jurnal Ilmu Manajemen (JIM), 7(1), 192-201.

Wulandari, P. A., Sinarwati, N. K., \& Purnamawati, I. G. A. (2017). Pengaruh Manfaat, Fasilitas, Persepsi Kemudahan, Modal, Return dan Persepsi Risiko terhadap Minat Mahasiswa untuk Berinvestasi Secara Online (Studi pada Mahasiswa Jurusan Akuntansi Program S1 Universitas Pendidikan Ganesha). JIMAT (Jurnal Ilmiah Mahasiswa Akutansi) Undiksha, 8(2).

Yuliardi, R., \& Nuraeni, Z. (2017). Statistika Penelitian: Plus Tutorial SPSS. Yogyakarta: Innosain.

Zulchayra, Z., Ibrahim, A., \& Fitria, A. (2020). Pengaruh Sosialisasi dan Pengetahuan terhadap Minat Investasi di Pasar Modal Syariah (Studi Pada Mahasiswa di Banda Aceh). JIHBIZ: Global Journal of Islamic Banking and Finance, 2(2), 138-155. 